\title{
PROTECTIVE EFFECT OF ASCORBIC ACID AND N-ACETYL CYSTEINE IN ASPARTAME INDUCED NEPHROTOXICITY IN ALBINO RATS
}

\author{
Walaa Ahmed Allam*, Sheren Farrag Mahmoud** and Ahmed Sedky Mahmoud*** \\ *Department of Forensic Medicine and Clinical Toxicology, Faculty of Medicine, Sohag University; \\ **Department of Pathology, Faculty of Medicine, Sohag University; \\ *** Department of Clinical Pathology, Faculty of Medicine, Sohag University
}

Corresponding author: Walaa Ahmed Allam

E-mail: dr_walaaallam@Yahoo.com

Tel: + (2)-01005538499

\begin{abstract}
Background: Aspartame is an artificial sweetener its consumption may cause some adverse health effects like metabolic syndrome, cancer and nephro-toxicity through oxidative stress of its metabolite. $\mathrm{N}$ acetyl cysteine (NAC) reduces kidney inflammation and improves renal function by improving microcirculation. Vitamin $\mathrm{C}$ is one of the most important antioxidant agents Aim of the study: to evaluate the protective effect of vitamin $\mathrm{C}$ and NAC in renal toxicity of aspartame either individually or in combination in albino rats Method: Rats were divided into 7 groups each group contains 6 rats administered the doses daily via gavages for 3 months; Group I: Negative control group, Group II: ascorbic acid in a dose of $200 \mathrm{mg} / \mathrm{kg}$ b.wt/day, Group III: NAC in a dose of $600 \mathrm{mg} / \mathrm{kg}$ body weight (b.wt)/day, Group IV: Aspartame (ASP) in a dose of $100 \mathrm{mg} / \mathrm{kg}$ b.wt. Group V: ASP plus ascorbic acid, Group VI: ASP plus NAC, Group VII: ASP plus a combination of NAC and ascorbic acid. The evaluation was by histopathological examination of kidney (by light microscope), biochemical evaluation. Results: Histopathological examination of group receiving aspartame showed marked chronic inflammatory cells infiltrates in the interstitial tissues with marked hydropic degeneration and pyknotic nuclei associated with increase level of serum urea and creatinine, Treatment by any of the Vitamin $\mathrm{C}$ or NAC showed similar picture of kidney improvement in the form of mild to moderate chronic inflammatory cells infiltrates in the interstitial tissues with mild hydropic degeneration, and decrease in level of seum urea and creatinine compared to asprtame treated group. Combined treatment of vitamin $\mathrm{C}$ and NAC with aspartame resulted in similar degree of histopathological recovery as when vitamin $\mathrm{C}$ and NAC used separately with aspartame with non significant change in level of seum urea and creatinine. Conclusion: vitamin $\mathrm{C}$ and NAC individually have protective effect of nephrotoxicity induced by aspartame. There are no statically different changes on combination of both vitamin $\mathrm{C}$ and NAC compared to when used individually to protect against aspartame induced renal changes.
\end{abstract}

Keywords: Aspartame, Vitamin C, NAC, Nephrotoxicity. 


\section{INTRODUCTION}

Artificial sweeteners are a group of food additives which provide sweet taste without increasing caloric intake. They can be also named; non nutritive sweeteners and high-intensity sweeteners (Shankar et al., 2013). Aspartame is a widely used artificial sweeteners worldwide (Magnuson et al., 2007). It is commonly present in drinks which have low calories and sweeteners which added to drinks as coffee and tea (Oyama et al., 2002).

Aspartame is made of two amino acids which are phenylalanine and the other is aspartic acid, these acids are components of our body proteins. Phenylalanine in aspartame modified by addition of a methyl group as it gives aspartame the final sweet taste (European Food Safety Authority, 2013).

Aspartame is converted in our GIT to aspartic acid and phenylalanine; they are absorbed and enter to the body. The methyl group of phenylalanine is released into the GIT to form methanol, which is absorbed by the body and used to produce energy (European Food Safety Authority, 2013).

Aspartame is an odorless, whitish powder, about 2 hundred times more sweetly than sucrose (Lean and Hankey, 2004). It is unstable during prolonged heating; therefore, it cannot be used for cooking (Chattopadhyay et al., 2014). The accepted intake of aspartame every day is $50 \mathrm{mg} / \mathrm{kg}$ and $40 \mathrm{mg} / \mathrm{kg}$ respectively, based on the United States and the European Union recommendations. (Marinovich et al., 2013), Although consumption of artificial sweeteners is considered to be safe in acceptable daily intake range, the results of some experimental and epidemiological studies showed that their consumption may cause some adverse health effects including obesity, metabolic syndrome (Swithers, 2013), cancer (Belpogg et al., 2006) and adverse neurobehavioral effects (Lindseth et al., 2007). As the kidney has an important role in excretion of various waste metabolites from the body, studies on nephrotoxic effect of artificial sweeteners, especially aspartame, have increased (Martins and Azoubel, 2007).

Methanol intoxication is accompanied with damage to mitochondria and microsomal proliferation also increased which lead to increase production of oxygen radicals (Castro et al., 2002). The above mentioned factors with excess of formaldehyde, which is formed during the acute methanol toxicity lead to increase in lipid peroxidation significantly (Parthasarathy et al., 2006).

$\mathrm{N}$-acetyl cysteine (NAC) is considered synthetic precursor of glutathione, NAC stimulates the intracellular synthesis of glutathione in the cells, and also it acts as a nucleophile to bind with the reactive metabolites and enhances the activity of glutathione Stransferase (GST) (Tylicki et al., 2003). NAC can reduce liability of nephrotoxicity which are occurred due to usage of contrast media as a dialysis requirement and also in 
patients undergoing angiography sessions (Al-Ghonaim and Pannu, 2006).

Vitamin $\mathrm{C}$ is one of the most important and essential water soluble vitamins for human health and is needed for many physiological functions in human body as prevention of oxidative stress (Naidu, 2003).

In the stress conditions ascorbic acid considered as the primary antioxidant intracellular and in the plasma (Padayatty et al., 2003).

The aim of the study to asses the protective effects of administration of vitamins $\mathrm{C}$ and NAC and compare their protection either individually or in combination in prevention of aspartame-induced nephrotoxicity of male albino rats. The evaluation was performed by histopathological examination of renal tissue and biochemical renal function tests.

\section{MATERIAL \& METHODS}

\section{Animals}

The study was performed on 42 sexually mature male albino rats (8 weeks old). The rats had been divided to 7 groups; every group was formed of 6 rats. Ethics and husbandry conditions of animal research were considered.

\section{Materials}

1. Pure ASP powder was purchased from Pharco Co.

2. NAC powder was purchased from Pharco Co.

3. Ascorbic acid powder was purchased from ElHadithah Co.

\section{Method}

- ASP: A dose of 100 $\mathrm{mg} / \mathrm{kg} /$ day (1/50 of LD50) administered daily by oral route through gastric tube for 90 days (Andress et al., 1973).

○ NAC: The therapeutic dose of NAC was applied (600 $\mathrm{mg} / \mathrm{kg}$ /day) (Saleh, 2014) by oral route through gastric tube for 90 days.

- Ascorbic acid: Dose of $(200 \mathrm{mg} / \mathrm{kg} /$ day) (Greggi et al., 2000) was administered orally through gastric tube for 90 days.

The rats had been divided to seven groups each group contains six rats;

Group I: Group of negative control: where Rats had not administered any of aspartame or antidotes.

Group II: Group of positive control: rats had administered ascorbic acid in dose of 200 $\mathrm{mg} / \mathrm{kg} /$ day dissolved in water and administered orally through gastric tube for 90 days.

Group III: Positive control group: Animals had received NAC in dose of $600 \mathrm{mg} / \mathrm{kg} /$ day which was dissolved in the water and administered orally through gastric tube for 90 days.

Group IV: Aspartame treated group: ASP was administered in dose of $100 \mathrm{mg} / \mathrm{kg}$ dissolved in water and administered orally through gastric tube daily for 90 days.

Group V: Animals had received ASP plus ascorbic acid. Ascorbic acid which is waterdissolved in dose of $200 \mathrm{mg} / \mathrm{kg} /$ day 
was administered orally through gastric tube. After an hour rats had received ASP $100 \mathrm{mg} / \mathrm{kg}$ orally through gastric tube daily for 90 days.

Group VI: Animals had received aspartame plus NAC. NAC was water dissolved and administered as $600 \mathrm{mg} / \mathrm{kg} /$ day orally through gastric tube. After an hour ASP dissolved in water in a dose of $100 \mathrm{mg} / \mathrm{kg}$ was administered orally through gastric tube daily for 90 days.

Group VII: Animals had received ASP plus a combination of NAC and ascorbic acid, NAC in a dose of $600 \mathrm{mg} / \mathrm{kg} /$ day and ascorbic acid in a dose of 200 $\mathrm{mg} / \mathrm{kg} /$ day both dissolved in water and administered orally through gastric tube. After an hour rats had received ASP $100 \mathrm{mg} / \mathrm{kg} /$ day orally through gastric tube for 90 days.

\section{Histopathological examination}

Animal sacrificed by cervical decapitation under ether anesthesia then histopathological examination of kidney was carried out to determine any associated changes that will be compared in animal groups. The kidney was dissected and fixed in Carnoy's solution $(60 \%$ absolute ethyl alcohol $+30 \%$ chloroform $+10 \%$ glacial acetic acid) for one hour, then processed for staining with hematoxylin and eosin (H\&E) stain (Drury and Wallington, 1967).

\section{Analytical examination:}

Before scarification blood samples were obtained from the retro-orbital plexus (Joslin, 2009) from all rats of all groups to estimate urea and creatinine levels.

1) Creatinine was done on

Roche /Hitachi COBAS C311 apparatus. It is depend upon conversion of creatinine with the help of creatinase, sarcosine oxidase to formaldehyde, glycine and hydrogen peroxide. hydrogen peroxide reacts with 4aminophenazone and HTIBa and form quinone imine chromgen with the help of catalyzaion of peroxidase .The color degree of quinone imine chromogen was directly proportional to the concentration of creatinine.

2) Urea was done on Roche /Hitachi COBAS C311 apparatus. The assessment of urea depend on test with urease and glutamate dehydrogenase . Unease hydrolyse urea to form ammonium and carbonate, after that 2-oxoglutarate will react with ammonium, glutamate dehydrogenase and the coenzyme NADH to produce Lglutamate. In that reaction two moles of NADH oxidized to NAD + for every mole of urea hydrolyzed. The rate of decrease in the concentration of NADH is proportionate directly to the urea concentration in the specimen and photometrically measured.

\section{Statistical analysis:}

The data were presented as mean \pm SD. Differences between the groups were determined by one way analysis of variance (ANOVA) and a post-hoc test of least significant difference (LSD) was assessed by SPSS software, version 17. $\mathrm{P}$ values less than 0.05 were statistically significant. 


\section{RESULTS}

\section{Evaluation of biochemical results}

The mean value of creatinine and urea levels in both NAC and vitamin $\mathrm{C}$ treated groups showed non significant changes when compared to negative control group as shown in table (1) and graph I (A\& B).

While the mean value of creatinine and urea levels in aspartame administered group (group IV) showed a very high significant increase $(\mathrm{P}<0.001)$ when compared to the group of negative control (group I), vitamin C (group II) and NAC (group III) treated groups as shown in table (2 \& 3) and graph I (A\& B).

Combination of aspartame and vitamin C (group V) showed very high significant decrease $(\mathrm{P}<0.001)$ in the mean value of urea and creatinine compared to aspartame treated group (group IV) as shown in table (4) and graph I (A\& B).

As regard comparison of aspartame + vitamin $\mathrm{C}$ treated group (group V) with aspartame + NAC treated group (group VI), there were non significant changes between the two groups in the mean value of urea and creatinine levels as shown in table (5) and graph I (A\& B).

Table (6) and graph I (A\& B) showed that the mean value of urea and creatinine levels in group of animals treated with aspartame plus combined vitamins $\mathrm{C} \& \mathrm{E}$ (group VII) there were non significant changes compared to aspartame plus vitamin $\mathrm{C}$ treated group (V) and aspartame plus NAC treated group (VI) respectively.

\section{Histopathological findings:}

In negative control group (I) and positive control groups (II \& III) the light microscopic examination of the kidney demonstrated normal histological appearance in the form of normal renal cortex which is composed of corpuscles, tubules, and in between there is minimal interstitial tissue. The corpuscles were consisted of some glomeruli which are surrounded by the bowman's spaces. The tubular lining cells were cuboidal to columnar and had a large rounded nucleus, with no signs of congestions or inflammation as shown in fig. (A1, A2 and A3)

Serial H\& E stained sections from kidney of animals treated with aspartame (Group IV) showed marked chronic inflammatory cells infiltrates in the interstitial tissues with necrosis of some renal tubules. Multiple renal tubules showed marked hydropic degeneration with pyknotic nuclei and vacuolated cytoplasm. Multiple renal glomeruli appear atrophic with widening of urinary spaces. Some of interstitial blood vessels show marked dilatation and congestion with occasional thickening of their walls as shown in fig. (B, C and D).

Groups treated with aspartame and vitamin $\mathrm{C}$ (group V) \& aspartame and NAC (group VI) and combination of vitamins $\mathrm{C} \& \mathrm{NAC}$ with aspartame (group VII) showed similar histological picture in the form of mild to moderate chronic inflammatory cells infiltrates in the interstitial tissues with mild 
hydropic degeneration. Interstitial blood vessels showed less dilatation and congestion in comparison to aspartame treated group as shown in fig. (E, F and $G)$. 
Table (1): Statistical analysis of the mean value of serum urea and creatinine in the negative control group (I) compared to antioxidant treated groups (II, III) using ANOVA (post-hoc test)

\begin{tabular}{|c|c|c|c|c|c|}
\hline \multirow{2}{*}{ Groups } & \multicolumn{3}{|c|}{ Mean \pm SD } & \multicolumn{2}{c|}{ P-Value } \\
\cline { 2 - 6 } Parameters & $\begin{array}{c}\text { Group I } \\
\text { (Negative control) }\end{array}$ & $\begin{array}{c}\text { Group III } \\
\text { (NAC) }\end{array}$ & $\begin{array}{c}\text { Group II } \\
\text { (Vitamin C) }\end{array}$ & $\begin{array}{c}\text { Negative control } \\
\text { Vs } \\
\text { (NAC) }\end{array}$ & $\begin{array}{c}\text { Negative control } \\
\text { Vs } \\
\text { (Vitamin C) }\end{array}$ \\
\hline Urea & $44.5 \pm 7.96$ & $47.33 \pm 10.81$ & $53.66 \pm 10.36$ & 0.682 NS & $0.189 \mathrm{NS}$ \\
\hline Creat. & $0.48 \pm .08$ & $0.56 \pm 0.09$ & $0.57 \pm 00.10$ & 0.428 NS \\
\hline
\end{tabular}

Table (2): Statistical analysis of the mean value of serum urea and creatinine in the aspartame treated group (IV) compared to negative control group (I) using ANOVA (post-hoc test)

\begin{tabular}{|c|c|c|c|}
\hline \multirow{2}{*}{ Groups } & \multicolumn{2}{|c|}{ Mean \pm SD } & P-value \\
\cline { 2 - 4 } Parameters & $\begin{array}{c}\text { Group IV } \\
\text { (aspartame) }\end{array}$ & \multicolumn{1}{c|}{$\begin{array}{c}\text { Group I } \\
\text { (negative control) } \\
\text { Vs } \\
\text { negative control }\end{array}$} \\
\hline Urea (mg/dl) & $106.67 \pm 20.36$ & $44.5 \pm 7.96$ & $0.000^{* * *}$ \\
\hline Creat. (mg/dl) & $1.62 \pm 0.47$ & $0.48 \pm .08$ & $0.000^{* * *}$ \\
\hline
\end{tabular}


Table (3): Statistical analysis of the mean value of serum urea and creatinine in the aspartam treated group (IV) compared to antioxidant treated groups (II, III) using ANOVA( post-hoc test)

\begin{tabular}{|c|c|c|c|c|c|}
\hline \multirow{2}{*}{$\begin{array}{c}\text { Groups } \\
\text { Parameters }\end{array}$} & \multicolumn{3}{|c|}{ Mean \pm SD } & \multicolumn{2}{|c|}{ P-Value } \\
\hline & $\begin{array}{l}\text { Group IV } \\
\text { (Aspartam) }\end{array}$ & $\begin{array}{l}\text { Group III } \\
\text { (NAC) }\end{array}$ & $\begin{array}{c}\text { Group II } \\
\text { (Vitamin C) }\end{array}$ & $\begin{array}{c}\text { Aspartam } \\
\text { Vs } \\
\text { (NAC) }\end{array}$ & $\begin{array}{c}\text { Aspartam } \\
\text { Vs } \\
\text { (Vitamin C) }\end{array}$ \\
\hline Urea & $106.67 \pm 20.36$ & $47.33 \pm 10.81$ & $53.66 \pm 10.36$ & $0.000 * * *$ & $0.000 * * *$ \\
\hline Creat. & $1.62 \pm 0.47$ & $0.56 \pm 0.09$ & $0.57 \pm 00.10$ & $0.000 * * *$ & $0.000 * * *$ \\
\hline
\end{tabular}

Table (4): Statistical analysis of the mean value of serum urea and creatinine in the aspartame treated group (IV) compared to aspartame + Vitamin C treated group (V), aspartame + NAC treated group (VI) and aspartame + combined vitamin C \& NAC treated group (VII) using ANOVA (post-hoc test)

\begin{tabular}{|c|c|c|c|c|c|c|c|}
\hline \multirow[t]{2}{*}{ Groups } & \multicolumn{4}{|c|}{ Mean \pm SD } & \multicolumn{3}{|c|}{ P-Value } \\
\hline & $\begin{array}{c}\text { Group IV } \\
\text { (aspartame) }\end{array}$ & $\begin{array}{c}\text { Group V } \\
(\text { aspartame+C) }\end{array}$ & $\begin{array}{c}\text { Group VI } \\
\text { (aspartame+NAC) }\end{array}$ & $\begin{array}{c}\text { Group VII } \\
(\text { aspartame+C+NAC) }\end{array}$ & $\begin{array}{l}\text { aspartame } \\
\text { Vs } \\
\text { (aspartame } \\
\text { + C) }\end{array}$ & $\begin{array}{l}\text { aspartame } \\
\text { Vs } \\
\text { (aspartame } \\
\text { + NAC) }\end{array}$ & $\begin{array}{c}\text { aspartame } \\
\text { Vs } \\
\text { (aspartame } \\
+\mathrm{C}+\mathrm{NAC})\end{array}$ \\
\hline Urea (mg/dl) & $106.67 \pm 20.36$ & $70.33 \pm 12.54$ & $71.00 \pm 7.45$ & $68.66 \pm 8.31$ & $0.000 * * *$ & $0.000 * * *$ & $0.000 * * *$ \\
\hline Creat. (mg/dl) & $1.62 \pm 0.47$ & $0.90 \pm 0.07$ & $0.89 \pm 0.11$ & $0.90 \pm 0.10$ & $0.000 * * *$ & $0.000 * * *$ & $0.000 * * *$ \\
\hline
\end{tabular}


Table (5): Statistical analysis of the mean value of serum urea and creatinine in the aspartame + vitamin C treated group (V) compared to aspartame + NAC treated group (VI) using ANOVA (post-hoc test)

\begin{tabular}{|c|c|c|c|}
\hline \multirow{2}{*}{$\begin{array}{r}\text { Groups } \\
\text { Parameters }\end{array}$} & \multicolumn{2}{|c|}{ Mean \pm SD } & \multirow{2}{*}{ P-Value } \\
\hline & $\begin{array}{c}\text { Group V } \\
\text { (aspartame }+C)\end{array}$ & $\begin{array}{c}\text { Group VI } \\
\text { (aspartame+NAC) }\end{array}$ & \\
\hline Urea $(\mathrm{mg} / \mathrm{dl})$ & $70.33 \pm 12.54$ & $71.00 \pm 7.45$ & $0.923 \mathrm{NS}$ \\
\hline Creat. (mg/dl) & $0.90 \pm 0.07$ & $0.89 \pm 0.11$ & $0.923 \mathrm{NS}$ \\
\hline
\end{tabular}

Table (6): Statistical analysis of the mean value of serum urea and creatinine in the aspartame + combined vitamin C \& NAC treated group (VII) compared to aspartame + vitamin $\mathrm{C}$ treated group $(\mathrm{V})$ and aspartame + NAC treated group (VI) using ANOVA( post-hoc test)

\begin{tabular}{|c|c|c|c|c|c|}
\hline \multirow{2}{*}{ Groups } & \multicolumn{3}{|c|}{ Mean \pm SD } & \multicolumn{2}{c|}{ P-Value } \\
\cline { 2 - 6 } Parameters & $\begin{array}{c}\text { Group VII } \\
\text { (aspartame + C }+ \\
\text { NAC) }\end{array}$ & $\begin{array}{c}\text { Group V } \\
\text { (aspartame + C) }\end{array}$ & $\begin{array}{c}\text { Group VI } \\
\text { (aspartame }+ \\
\text { NAC) }\end{array}$ & $\begin{array}{c}\text { (aspartame + C + NAC) } \\
\text { Vs } \\
\text { (aspartame + C) }\end{array}$ & $\begin{array}{c}\text { (aspartame + C + NAC) } \\
\text { Vs } \\
\text { (aspartame + NAC) }\end{array}$ \\
\hline Urea (mg/dl) & $68.66 \pm 8.31$ & $70.33 \pm 12.54$ & $71.00 \pm 7.45$ & $0.809 \mathrm{NS}$ & $0.735 \mathrm{NS}$ \\
\hline Creat. $(\mathrm{mg} / \mathrm{dl})$ & $0.90 \pm 0.10$ & $0.90 \pm 0.07$ & $0.89 \pm 0.11$ & $0.977 \mathrm{NS}$ & $0.943 \mathrm{NS}$ \\
\hline
\end{tabular}

$\mathrm{P}$ values are shown as: $* \mathrm{P} \quad<0.05$ (significant), $\quad * * \mathrm{P}<0.01 \quad$ (highly significant) $* * * \mathrm{P}<0.001$ (very highly significant) NS: Non significant. SD: Standard deviation 

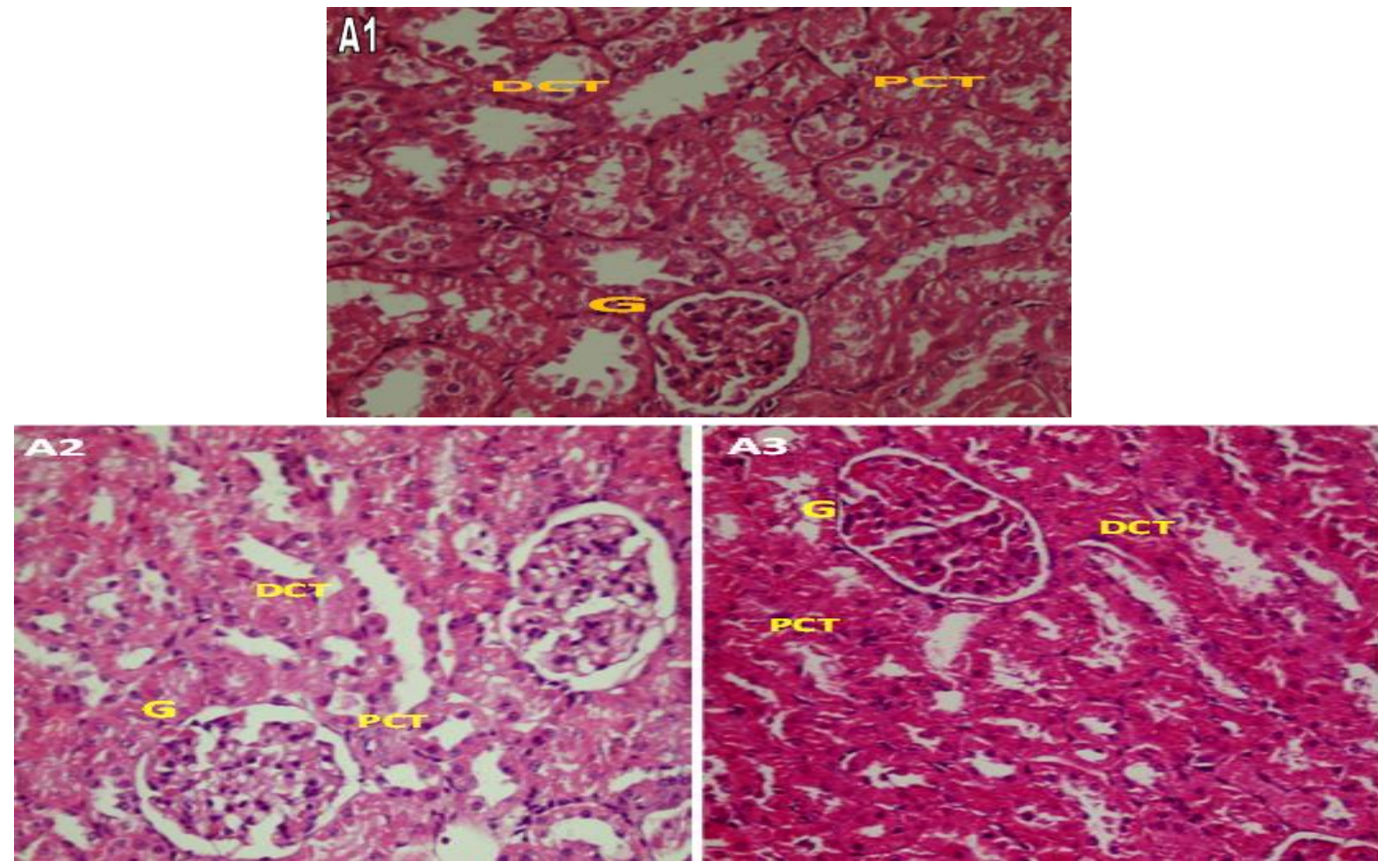

Figures (A1, A2, A3): A photomicrograph of a section in the kidney of the negative control, vitamin C, NAC treated groups respectively showing normal renal glomerulus (G), proximal convoluted tubules (PCT) and distal convoluted tubules (DCT). 

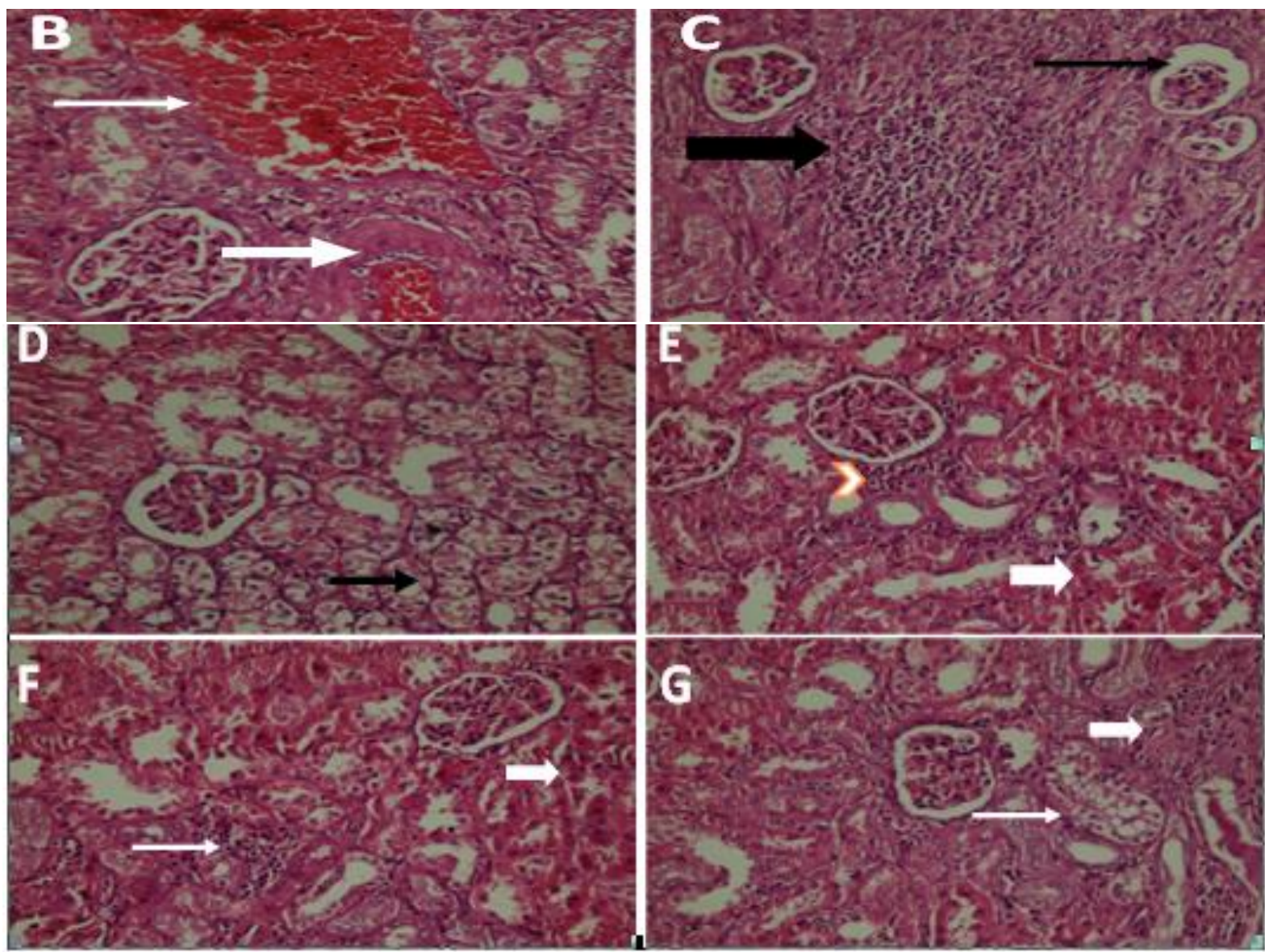

Figures (B,C,D): A section in the kidney of group receiving aspartame, (B), showing marked dilatation and congestion of some peritubular blood vessels \{thin arrow $\}$ with thickening of wall of others $\{$ thick arrow $\},(C)$, marked interstitial chronic inflammatory cells infiltrates with necrosis of some renal tubules \{thick arrow $\}$, atrophy of some renal glomeruli and widening of their urinary spaces \{thin arrow $\}$, (D), both PCT and DCT epithelial lining showing marked hydropic degeneration with pyknotic nuclei and marked vacuolated cytoplasm \{arrow . Figure (E): A section in the kidney of group receiving aspartame $+\mathrm{C}$ showing mild interstitial chronic inflammatory cells infiltrates \{arrow head\} with mild degenerative changes of both PCT and DCT epithelial lining showing pyknotic nuclei and increased cytoplasmic eosinophilia \{thick arrow $\}$. Figure (F): A section in the kidney of group of asartam + NAC showing mild interstitial chronic inflammatory cells infiltrates \{thin arrow $\}$ with mild degenerative changes of both PCT and DCT epithelial lining \{thick arrow . Figure $(\mathbf{G})$ : a section from group receiving aspartame $+\mathrm{C}+\mathrm{NAC}$ showing mild hydropic degeneration of both PCT and DCT epithelial lining with pyknotic nuclei and mild vacuolated cytoplasm \{thin arrow $\}$ with minimal inflammation $\{$ thick arrow H\&E staining $x 400$. 


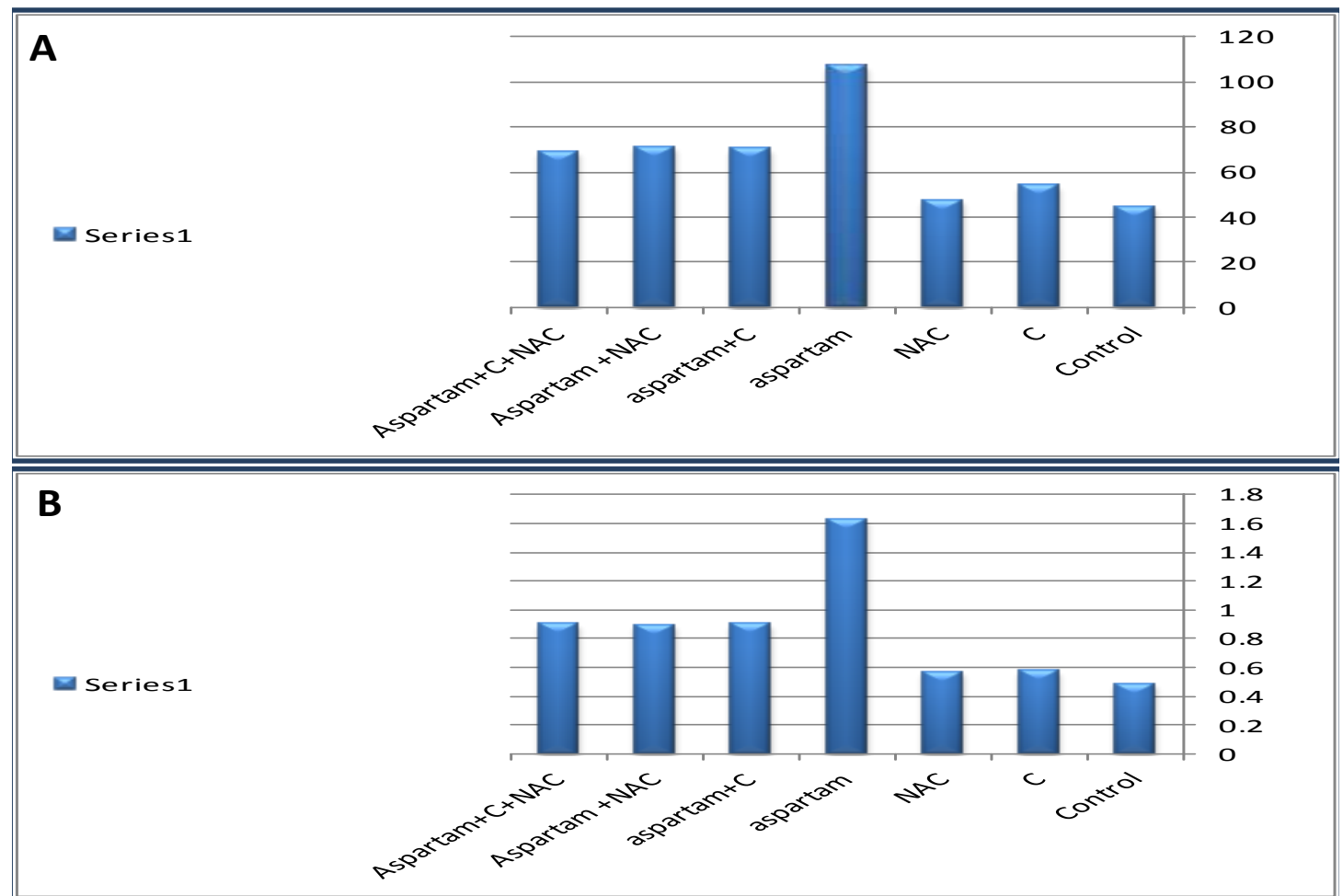

Graph I: (A) The mean value of urea serum level in different groups

(B) The mean value of creatinine serum level in different groups

\section{DISCUSSION}

Aspartame is a widely employed synthetic sweetener used in diet control and its safety based on the findings of the previous studies showed controversy. The present work was performed to evaluate the effect of co-treatment with vitamins $\mathrm{C}$ and NAC and compare their protection either individually or in combination in prevention of aspartame-induced renal changes of the male albino rats.

In present work mean value of urea and creatinine levels in aspartame treated group showed very highly significant increase as compared to control groups.

An increase in serum creatinine level is considered an early sign of malfunctioning of the glomeruli, so the level of serum creatinine is considered one of the most widely used serum markers in estimating glomerular filtration rate (Nitescuet al., 2006), so increase creatinine level in the present study was an indicator of GFR affection by aspartame and these biochemical results were confirmed by histopathological changes of aspartame treated group of the present study which showed atrophic glomeruli with widening of urinary spaces, marked hydropic degeneration of renal tubules with foci of interstitial mononuclear inflammatory cells infiltration, with congested vasculature and thickening of blood vessel wall.

This is in accordance with Amin et al., 2016 who observe marked elevation in creatinine and urea due to the aspartame toxic 
effect on kidney and induce nephritic damage. These effects diminished glomerular filtration average and reservation of urea and creatinine.

The kidney dysfunction in aspartame can be explained by that aspartame administration increases the level of plasma methanol (Davoli, 1986), which is metabolized to formaldehyde and after that formate, which is associated with the formation of electrophilic compounds (Parthasarathy et al., 2006). These alterations may contribute to methanol intoxication that increased levels of electrophilic compounds (Abhilashet al., 2011).

Endogenous glutathione could attack electrophilic centers, so protect the proteins, lipids and nucleic acids from the harmful effect of electrophilic compounds which has the ability to reacte with their SH- groups (Ahluwaliaet al., 1996). Which lead to glutathione depletion, this depletion has a great action in the pathogenesis of nephropathy through direct effects and on the other hand by affecting the molecular mechanisms which control kidney inflammation (Ebaid et al., 2013).

Also increase in creatinine in case of aspartame can be explained by sudden fall in GFR because of the majority of methanol, the by product of administrated aspartame metabolism that enters specifically the proximal tubular epithelial cells, binds to anionic phospholipids in the cells, this lead to abnormalities in the function and the metabolism of many membranes and organelles in the cells then develop harmful effects to epithelial cells of the proximal tubules of the kidney which ended as a renal failure (Parthasarathy et al.,2006).

The results of the present work were in agreement with the results recorded by Saleh, 2014 who stated that oral administration of aspartame for 42 days significantly increased urea and creatinine in serum in the experimental groups, also Bahr and Zaki, 2014 showed that oral administration of water which contain $0.25 \mathrm{~g} / \mathrm{L}$ of aspartame for 60 days significantly increased blood urea nitrogen, serum creatinine, and potassium levels in male rats. Tada et al., 2008 reported that the subchronic oral use of aspartic acid for 90 days led to decreased blood urea nitrogen, creatinine and uric acid levels associated with raised urinary ketone and protein.

In the present study, animals treated with aspartame showed marked chronic inflammatory cells infiltrates in the interstitial tissues with necrosis of some renal tubules. Some renal tubules showed marked hydropic degeneration. Multiple renal glomeruli appear atrophic with widening of urinary spaces. Some of interstitial blood vessels show marked dilatation and congestion with occasional thickening of their walls.

The above results can be explained as the cortex receives the largest amount of blood flow to the kidney compared to other kidney parts. So, when a toxin reach to the kidney by blood, a large amount of it will reach the cortex this could explain why the cortex of kidney more affected than other 
kidney parts (Oyama et al., 2006). The changes in the renal tubules in the form of pyknotic nuclei may be due to damage to DNA as a result of formaldehyde exposure, as formaldehyde leads to breakdown and after that cross link in the genetic material. So chronic usage of aspartame may leads to nucleic acids damage especially DNA which induces apoptotic changes in most of the renal tubule padding cells (Trocho et al., 1998).

This in accordance with AlEisa et al., 2018 who mentioned that aspartame administration produces large histological structural alterations in renal tissue, in the form of dilution in the lumen of the proximal and distal tubules in aspartame treated rats, mainly in the cortex, also in agreement with Ghavidel et al., 2018 who stated that renal tissue evaluation revealed degeneration of proximal and distal convoluted tubules; glomerular atrophy and increasing of urinary space after aspartame consumption in rats. Similar findings were also reported by Waggas et al., 2015 in female rats fed with $50 \mathrm{mg} / \mathrm{d}$ and $150 \mathrm{mg} / \mathrm{d}$ of aspartame for 6 months, along with significant structural changes in their renal tubules compared to a control group.

The results of the present work were in agreement with Naik, 2018 who stated that usage of aspartame in fetal kidneys of rats produce alteration in the nuclei of the cells of glomeruli, collecting ducts, proximal and distal convoluted tubules with increase in the cell volume and decrease in number of cells in rats fetal kidneys which explain the nephrotoxicity of aspartame.

Also the result of the present study was in agreement of Zararsiz et al., 2007, who found that in rats treated with formaldehyde as one of aspartame's metabolites, there were degenerated glomerulei and vacuolization and dilation of the distal tubules. Also Tada et al., 2008 found that use of aspartic acid for 90 days led to degeneration of renal tubules and tubular dilatation were observed with an increased kidney weight.

In the present study, urea and creatinine changes that were induced by aspartame exposure were partially normalized when vitamin $\mathrm{C}$ was given together with aspartame and when NAC was given together with aspartame. Administration of vitamin $\mathrm{C}$ and NAC individually with aspartame showed no statistical significant difference in urea and creatinine levels compared to group received combination of vitamins $\mathrm{C} \& \mathrm{NAC}$ with aspartame.

Histopathological picture of animals treated with aspartame plus vitamin C, aspartame plus NAC and combination of vitamins $\mathrm{C} \& \mathrm{NAC}$ with aspartame be through with above mentioned biochemical results as it showed improvement in the kidney structure in the form of mild to moderate chronic inflammatory cells infiltrates in the interstitial tissues with mild hydropic degeneration. Interstitial blood vessels showed less dilatation and congestion in comparison to aspartame treated group.

These results in agreement with Saleem, 2012 who mentioned that 
combination of vitamin $\mathrm{C}$ and Nigella sativa oil had nephroprotective effect as they lowered the values of nephrotoxicity indicators (serum creatinine, blood urea nitrogen, and antioxidant activity). When these two antioxidants were given as combination, they proved to have synergistic nephroprotective effect.

Protective effect of vitamin $\mathrm{C}$ may result from its effect on normalizing the uric acid level that decreased by aspartame (Tada et al., 2008). Uric acid is a major antioxidant in human plasma and acts as radical scavenger (Becker et al., 1989). Vitamin $C$ also may protect vitamin $\mathrm{E}$ and increase its concentration which is also act as free radicals scavenger (Winkler, 1992).

The treatment of kidney with Lcarnitine (LC) and aspartame showed an improvement in renal corpuscles. Therefore, it is possible that LC could produce beneficial effects against ASP damage of kidney (Al-Eisa et al., 2018). Ascorbic acid is a cofactor for several enzymes participating in the post-translational hydroxylation of collagen, in the biosynthesis of carnitine. So vitamin $\mathrm{C}$ has important role against toxin induced nephrotoxicity (Hacisevkđ, 2009).

The metabolites which are formed during methanol oxidation (one of the metabolites of aspartame) can cause formation of protein peroxides, which lead to damage and fragmentation of proteins, changing its properties and losing of its enzymatic activities (Skrzydlewska et al., 2000).
NAC found to prevent nephrotoxicity and morphological injury to the kidney, also decrease neutrophilic infiltration, and it also improve renal clearance disturbance (Mazzon et al., 2001).

NAC restore the normal glutathione activity (Kadiska et al., 2000) and participates in the regeneration of endotheliumderived relaxing factor and glutathione (Hosseinjani et al., 2013).

It inhibits the induction of proinflammatory cytokines and blocks the tumour necrosis factor- $\alpha$ (TNF$\alpha$ ) induced apoptotic cell death (Nishino et al., 2002), also NAC has been demonstrated to be effective in the prevention of hypoperfusion and toxin induced renal failure (Mazzon et al., 2001).

So NAC prevent nephrotoxicity by improving renal haemodynamics, prevention of renal apoptosis and by avoiding direct oxidative tissue damage (Tariq et al., 1999).

These results were in agreement with the results recorded by Saleh, 2014 who found that oral administration of aspartame for 42 days resulted in decrease level of urea and creatinine in animals administered NAC and folic acid in combination with aspartame.

Also Finamor et al., 2014 recorded that NAC causes elevation of ascorbic acid level and reduction of creatinine in aspartame treated animals administered aspartame orally for 6 weeks (40 mg/kg).

\section{CONCLUSION}


Our findings indicate that administration of vitamin $\mathrm{C}$ and/or NAC has a protective effect against nephrotoxicity induced by aspartame. There is no difference in protective effect from combined use of both vitamin $\mathrm{C}$ and NAC versus their individual use with aspartame.

\section{REFERENCES}

Abhilash, M.; Paul, M.V.S.; Arghese, M.V. V. and Nair, R.H. (2011): Effect of long term intake of aspartame on antioxidant defense status in liver. Food Chem.Toxicol., 49:1203-1207.

Ahluwalia, P.; Tewari, K. and Choudhary, P. (1996): Studies on the effects of monosodium glutamate (MSG) on oxidative stress in erythrocytes of adult male mice. Toxicol. Lett., 84:161-165.

Al-Eisa, R.A.; Hamza, R.Z.; Mehana, A.E. and ElShenawy, N.S. (2018): The Influence of L-carnitine on Aspartame Toxicity in Kidney of Male Rats. International Journal of Pharmacology, 14: 1118-1127.
Al-Ghonaim, M. and Pannu, N. (2006): Prevention and treatment of contrast-induced nephropathy.Tech. Vasc. Interv.Radiol., 9: 42-49.

Amin, K.A.; H.M. Al-Muzafar, and A.H. Abd Elsttar, (2016): Effect of sweetener and flavoring agent on oxidative indices, liver and kidney function levels in rats. Indian J. Exp. Biol., 54: 56-63.

Andress, J.M.; Martinez, T., and Youkilis, G. (1973): E-046. SC18862: Acute toxicity studies in the rat, mouse, and rabbit. G.S. Searle \& Co., Skokie, Illinois

Bahr, H.I. and Zaki, M.S. (2014): Renal genomic instability induced by aspartame and the possible influence of the flaxseed oil and coenzyme Q10 in male rats. Life Sci. J., 11:301-308.

Becker, B.F.; Reinholz, N.; Ozcelik, T.; Leipert B. and Gertach, E. (1989): Uric acid as radical scavenger and 
antioxidant in the heart. Pflugers. Arch., 415: 127-135.

Belpogg, F.; Morando, S.; Michela, P.; Davide, D.; Michelina, L. and Franco, M. (2006): Results of long-term carcinogenicity bioassay on Sprague-Dawley rats exposed to aspartame administered in feed. Ann. N. Y. Acad. Sci., 1076:559-577.

Castro, G.D.; Costantini, M.H.; Delgado de layno, A.M. and Castro, A. (2002): Rat liver microsomal and nuclear activation of methanol to hydroxyl methyl free radicals. Toxicol. Lett., 129(3): 227236.

Chattopadhyay, S.; Raychaudhuri, U. and Chakraborty, R. (2014): Artificial sweeteners - a review. J. Food Sci. Technol., 51:611-621.

Davoli, E. (1986): Serum Methanol Concentrations in Rats and in Men After a Single Dose of Aspartame. Food and Chemical Toxicology, 24(3):187-189.
Drury, R.A. and Wallington, E.A. (1967): Carleton's Histological Technique. $4^{\text {th }}$ ed. Oxford University press: 114.

Ebaid ， H.; Samir, A.E.; Bashandy,I.; Alhazza, M.; Rady, A. and El-Shehry, S. (2013): Folic acid and melatonin ameliorate carbon tetrachloride-induced hepatic injury, oxidative stress and inflammation in rats. Nutrition \& Metabolism, 10: 20.

\section{European Food Safety Authority} (2013): Scientific Opinion on the re-evaluation of aspartame (E 951) as a food additive. EFSA Journal, 11(12): 3496.

Finamor, I.; Pavanato, M. A.; Pês, T.; Ourique, G.; Saccol, E.; Schiefelbein, S. et al. (2014): $\mathrm{N}$-acetylcysteine protects the rat kidney against aspartameinduced oxidative stress. Free Radical Biology and Medicine, 75 (1): 30 .

Ghavidel, S.; Davari, S.A. and Rasekh, M. (2018): Comparison of The Antioxidant Effect Of Vitamin E And Curcuma Longa L. 
Extract On The

Histopathological Lesions Of

Liver And Kidney Following Aspartame Consumption In Rat. Journal of Comparative Pathobiology Iran, 15 (2):25312540 .

Greggi, A. I. M.; Joanad'arc, C. D. And Maria, D. P. (2000): Protective Effects of Vitamin C Against Cisplatin-Induced Nephrotoxicity and Lipid Peroxidation in Adult Rats: A Dose-Dependent Study. Pharmacological Research, 41 (4): 405-411.

Hacisevkd, A. (2009): An Overview of Ascorbic Acid Biochemistry. J. Fac. Pharm. Ankara, 38 (3): 233-255.

Hosseinjani, H.; Moghaddas, A. and Khalili, H. (2013) Nacetylcysteine for the prevention of non-contrast media agent-induced kidney injury: from preclinical data to clinical evidence. Eur. J. Clin. Pharmacol., 13 :1494-1498.

Joslin, J. (2009): Blood collection: Techniques in exotic small mammals. J. Exotic. Pet. Med., 18(2): 117-139.

Kadiska, M.B.; Gladen, B.C.; Baird, D.D.; Dikalov, A.E.; Sohal, R.S.; Hatch, G.B. et al. (2000): Biomarkers of oxidative stress study: are plasma antioxidants markers of $\mathrm{CCl} 4$ poisoning? J. Free. Rad.Biol. Med., 28:838-845.

Lean, M.E.J. and Hankey, C.R. (2004): Aspartame and its effects on health. $\mathrm{Br}$ Med J., 329:755-756.

Lindseth, G.N.; Coolahan, S.E.; Petros, T.V.; Linseth, P.D.; Magnuson, B.A.; Burdock, G.A. et al. (2007): Aspartame: a safety elevation based on current use levels, regulations, and toxicological and epidemiological studies. Crit. Rev. Toxicol., 37(8): 629-727.

Marinovich, M.; Galli, C.L.; Bosetti, C.; Gallus, S. and La Vecchia,

C. (2013): Aspartame, lowcaloriesweeteners and disease:regulatorysafety and epidemiological issues. Food Chem. Toxicol., 60: 109-115. 
Martins, M.R.I. and Azoubel, R. (2007): Effects of aspartame on fetal kidney: a morphometric and stereological study. Int. J. Morphol., 25: 689-694.

Mazzon, E.; Britti, D.; De Sarro, A.; Caputi, A.P. and Cuzzocrea, S. (2001): Effect of $\mathrm{N}$-acetylcysteine on gentamicin-mediated nephropathy in rats. Eur. J. Pharmacol. 424:75-83.

Naidu, A. (2003): Vitamin $\mathrm{C}$ in human health and disease is still a mystery? An overview. Nutrition Journal, 2: 7.

Naik, A.K.; Zafar, T. and Vinoy, K. S. (2018): Health Implications Associated with Aspartame Consumption: A Substantial Review, 21(3):127134.

Nishino, Y.; Takemura, S. and Minamiyama, Y. (2002): Inhibition of vancomycin induced nephrotoxicity by targeting superoxide dismutase to renal proximal tubule cells in the rat. Redox Rep., 7: 317-319.
Nitescu, N.; Ricksten, $\quad$ N.; Marcussen, B.; Haraldsson, U.; Nilsson, S.B. and Guron, G. (2006): N-Acetylcysteine attenuates kidney injury in rats subjected to renal ischaemiareperfusion. Nephrol. Dial. Transplant., 21:1240-1247.

Oyama, Y.; Sakai, H.; Arata, T.; Okano, Y.; Akaike, N.; Sakai, K. and Noda, K. (2002): Cytotoxic effects of methanol, formaldehyde and formate on dissociated rat thymocytes: a possibility of aspartame toxicity. Cell Biol. Toxicol., 18(1): 43-50.

Oyama, Y.; Sakai, H.; Arata, T.; Okano, Y. and Akaike, N. (2006): Effects of aspartame on the exocrine pancreas of rat fetuses. Int. J. Morphol., 24:679-684.

Padayatty, S.J.; Katz, A.; Wang, Y.; Eck, P.; Kwon, O.; Lee, J.H. et al. (2003): Vitamin C as an antioxidant: Evaluation of its role in disease prevention. $\mathrm{J}$. Am. Coll. Nutr., 22(1): 18-35.

Parthasarathy, J.N.;

Ramasundaram, S.K.; 
Sundaramahalingam, M. and

Pathinasamy, S.D. (2006):

Methanol induced oxidative stress in rat lymphoid organs. J. Occup. Health. 48, 20-27.

Saleh, A.A. (2014): Synergistic effect of $\mathrm{N}$-acetyl cysteine and folic acid against aspartameinduced nephrotoxicity in rats. International Journal of Advanced Research, 2(5): 363373.

Saleem, U.; Bashir, A.; Kanwal, R.; Saeed, M.; Maqsood, A. and Alia, E. (2012): Nephroprotective effect of vitamin $\mathrm{C}$ and Nigella sativa oil on gentamicin associated nephrotoxicity in rabbits. Pak. J. Pharm. Sci., 25(4): 727-730

Shankar, P.; Ahuja, S. and Sriram, K. (2013): Non-nutritive sweeteners: review and update. Nutrition, 29:1293-1299.

\section{Skrzydlewska, E.; Elas, M.;} Farbiszewski, R. and Roszkowska, A. (2000): Effect of methanol intoxication on free-radical induced protein oxidation. J. Appl. Toxicol., 20 (3):239-243.
Swithers, S.E. (2013): Artificial sweeteners produce the counterintuitive effect of inducing metabolic derangements. Trends Endocrinol. Metab., 24:431441.

Tada, Y.; Yano, N. and Takahashi, H. (2008): Toxic effects of 1aspartic acid at high dose levels on kidneys and salivary glands in Fischer 344 rats detected in a 90-day feeding study. Food and Chemical Toxicology Journal, 46: 2789- 2795.

Tariq, M.; Morais, C. and Sobki, A. (1999): N-acetylcysteine attenuates cyclosporin-induced nephrotoxicity in rats. Nephrol. Dial. Transplant, 14: 923 -929. Trocho, C.; Pardo, R.; Rafecas, I.; Virgili, J.; Remesar, X.; Lopez, J.A. and Alemany, M. (1998): Formaldehyde derived from dietary aspartame binds to tissue components in vivo. Life Sci., 63:337-349.

Tylicki，L.; Rutkowski，B. and Horl, W.H. (2003): Antioxidants: a possible role in 
kidney protection. Kidney

Blood Press Res. 26: 303-314.

Waggas, A.; Soliman, K.;

Moubarz, G.; Abd Elfatah, A.

and Taha, M. (2015): Potential

protective effects of aqueous

extract of Majoram leaves, against aspartame induced renal toxicity in female rats. Am. J. Toxicol. Sci., 7:267-278.

Winkler, B.S. (1992): Unequivocal evidence in support of the non enzymatic redox coupling between glutathione/glutathione disulfide and ascorbic acid/dehydro ascorbic acid. Biochim Biophys Acta., 1117: 287-290.

Zararsiz, I.; Sarsilmaz, M. and Tas, U. (2007): Protective effect of melatonin against formaldehyde induced kidney damage in rats. Toxicology and Industrial Health Journal, 23: 573-579. 


\section{الملخص العربيى}

الأثر الوقائي لحمض الأسكوربيك و ن- أستيل السيستين على تسمم الكلي الناتج عن تأثير

\section{مادة الأسبارتام في الفئران البيضاء}

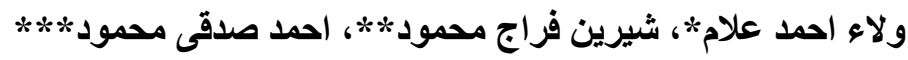

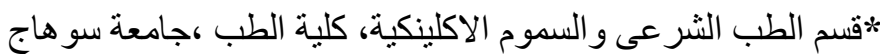

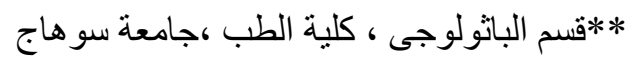

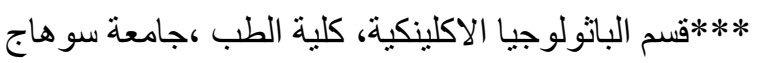

الأسبارتام هو مركب صناعي يستخدم فى التحلية قد يسبب استهلاكه بعض الآثار الصحية الضـارة مثل متلازمـة

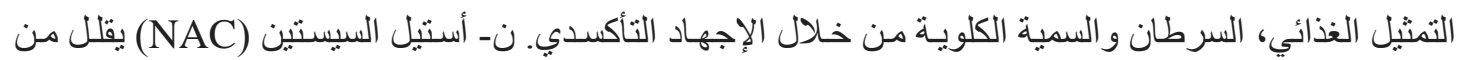
التهاب الكلى ويحسن وظائف الكلى من خـلال تحسين الدورة الدمويـة الدقيقة. حمض الأسكوربيك (فيتامين ج) يعتبر أحد أهم العوامل المضادة للأكسدة.

الهدف من الاراسة: تقييم التأثير الوقائي لفيتامين ج و ـ نـ أستنيل السيستين في السمية الكلويـة للأسبارتام إمـا بشكل فردي أو مزدوج في الجرذان البيضاء. الطريقة: تم تقسيم الجرذان إلى 7 مجمو عات تحتوب كل مجموعة على على 6 فئر ان وتؤخذ الجر عات يو ميا عن

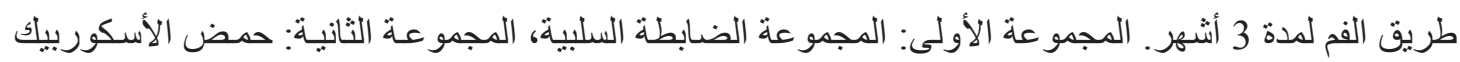

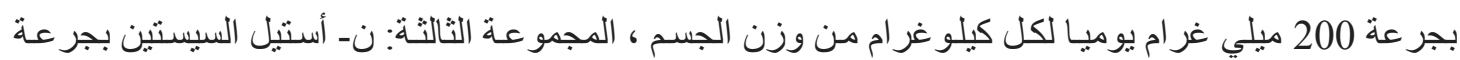

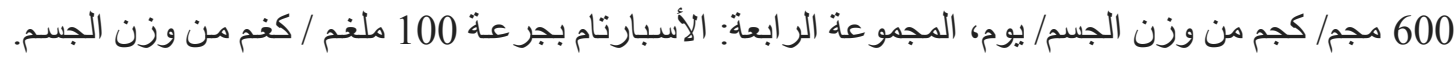
المجمو عة الخامسة: الأسبارتام بالإضافة إلى حامض الأسكوربيك، المجمو عة السادسة: الأسبارتام مع نـ نـ أستنيل

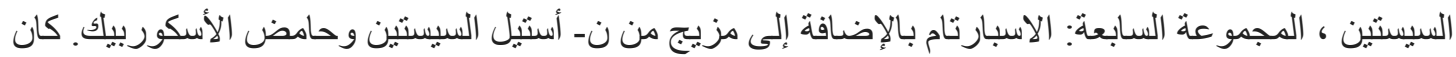
التقييم عن طريق فحص النسيج الكلوي (بو اسطة الميكروسكوب الضوئي)، والتقييم الكيميائي الحيوي.

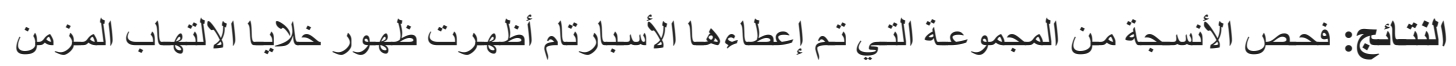
،إرتشاح ملحوظ في خلايا الأنابيب الكلوية مع التنكس الخلوى المائي واحتقان بعض الأو عية الدموية في الأنسجة

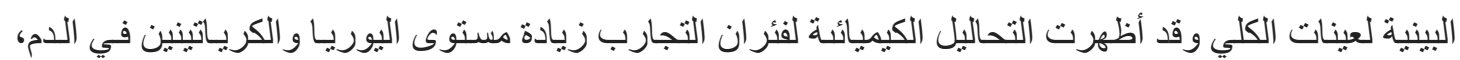

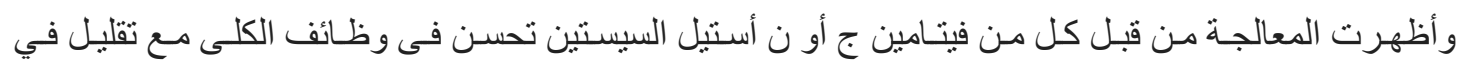

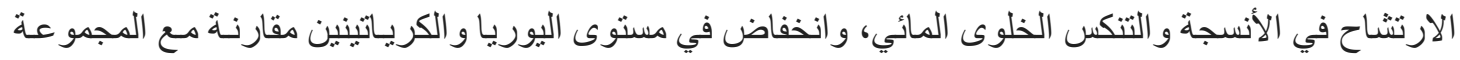

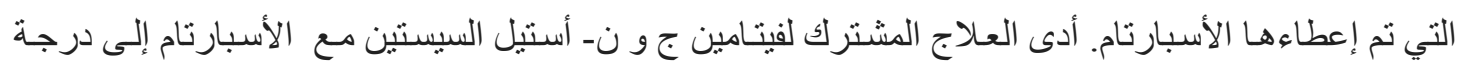

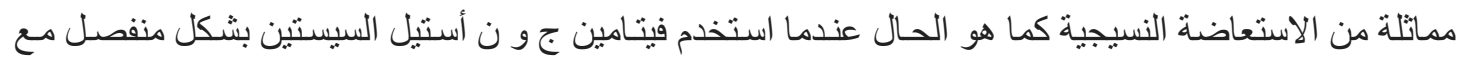
الأسبارتام ولم ينتج تغيير ذات قيمة في مستوى اليورياو الكرينتين. الاستنتاج : فيتامين ج و ن- أستيل السيستين بشكل فردي لهما نأثير وقائي للسمية الكلوية الناجم عن الأسبارتام.

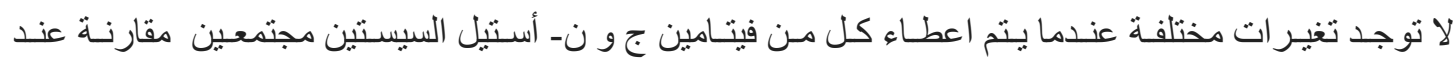
استخدامها بشكل منفرد للحماية من التغير ات الكلوية الناتجة عن الأسبارتام. 